\title{
Introduction
}

\section{James Croll - bicentenary and biography, from janitor to genius}

\section{Kevin J. EDWARDS}

\author{
Departments of Geography \& Environment and Archaeology, School of Geosciences, University of Aberdeen, \\ Elphinstone Road, Aberdeen AB24 3UF, UK;McDonald Institute for Archaeological Research and Scott Polar \\ Research Institute, University of Cambridge, Cambridge UK. \\ Email: kevin.edwards@abdn.ac.uk
}

How did a man who grew up on a croft in Scotland, with little schooling, reach the pinnacle of $19^{\text {th }}$ century scientific achievement as a climate change pioneer, become a correspondent of Darwin amongst others, and then almost disappear from general awareness? This volume addresses the life and work of one such remarkable person.

James Croll (1821-1890; Fig. 1) was raised in rural Perthshire and left school at 13 years of age, considering himself to be a 'dull scholar'. He set a seemingly random course through sundry occupations, including millwright, tea merchant, temperance hotelier and insurance salesman. As a 36-year-old and in-between jobs, he published anonymously a book titled The Philosophy of theism: an inquiry into the dependence of theism on metaphysics and the only possible way of arriving at a proof of the existence of God (Anon. 1857). Seven years later and a janitor in Glasgow, his article 'On the physical cause of the change of climate during geological epochs' (Croll 1864) came to be recognised widely as a landmark contribution to an understanding of climate change. In 1876, with over 60 scientific papers and notes to his credit and a year after the appearance of his monumental volume Climate and time in their geological relations (Croll 1875), he was elected a Fellow of the Royal Society of London, became an Honorary Member of the New York Academy of Sciences, and he was awarded an honorary doctorate by the University of St Andrews. Croll was now in his $55^{\text {th }}$ year and an office manager with the Geological Survey of Scotland in Edinburgh. Half a decade on, James Croll retired owing to ill health and after a lifetime of money worries he died shortly before his $70^{\text {th }}$ birthday having two weeks previously seen a copy of his final book, The philosophical basis of evolution (Croll 1890).

In 2012, Bol'Shakov et al. (2012, p. 202) observed:

Croll was the first to consider the effect of positive feedback, which increased the effect of orbital variation of insolation and transformed that variation into global climate change, that is into glaciations and interglacial periods. That is the main achievement of his theory, and to our mind, is the most important discovery in paleoclimatology. Its consequences are not yet sufficiently recognised.

Sadly, Croll's reputation was diminished by the time of his death. He had misjudged the contemporaneity of interhemispheric, glacial-interglacial cyclicity, and his chronological estimates were out of harmony with later evidence. This should not have negated the impact and influence of his basic arguments, even if it was to be well into the $20^{\text {th }}$ century before
Serbian mathematician Milutin Milankovitch (Milanković; 1879-1958) and palaeoceanographers were able take matters forwards, albeit with varying reference to Croll (Milankovitch 1930, 1941; Hays et al. 1976). A recent celebration of Milankovitch (admittedly a brief one) ignored Croll (Cvijanovic et al. 2020), yet others have been confident in promoting the claims of the Scot when citing the 'Croll-Milankovitch' theory or variations upon that theme (cf. Fairbridge 1961; Goudie 1983; Rogers 1993; Muller \& MacDonald 1997).

Leaning heavily on the tome by Irons (1896), Croll's life and work have been written about sporadically (cf. Alexander 1900; Bailey 1952; Imbrie \& Imbrie 1979; Pearce 2018). It might be argued that since his death, many aspects of Croll's life and achievements have flickered beneath the radar of popular and scientific consciousness (though see Hamlin 1982; Tasch 1986; Fleming 2006; Hilgen 2010; Finnegan 2012; Sugden 2014). Given that 2021 marks the bicentenary of his birth, it seemed apt to review aspects of his biography. This Special Issue of Earth and Environmental Science Transactions of the Royal Society of Edinburgh contains a series of invited papers which address the question of James Croll, the man and the scientist.

\section{Biography}

The principal phases of Croll's life are well known thanks to the publication of his autobiographical essay and the biography within the volume collated by his friend James Campbell Irons (1896). The Autobiographical sketch of James Croll: with memoir of his life and work tells of an early existence within rural Perthshire, where his Congregationalist father was both a crofter and a stonemason. Croll was one of four sons, two of whom died young, and his childhood was characterised by a pain around the fontanelle and a rudimentary schooling because, he thought, his parents were 'judiciously opposed to too early mental work' (Croll 1887, p. 11). Aged 11, happenstance led to an acquaintance with the new Penny Magazine, an illustrated, mass-circulation publication aimed at the education of the working classes. It provided the impetus to drive Croll's selfeducation, especially in the sciences, and 'with assistance from no one' he found that it was the beauty and simplicity associated with laws and principles, rather than facts and details, which 'riveted' him. Academic development was delayed by the need to leave school at 13 years of age in order to help his mother on the croft while his father worked away from home.

Allusion has already been made to James's engagement with different professions. Following a brief spell of office work with

(C) The Author(s), 2021. Published by Cambridge University Press on behalf of The Royal Society of Edinburgh. This is an Open Access article, distributed under the terms of the Creative Commons Attribution licence (http://creativecommons.org/licenses/by/4.0/), which permits unrestricted re-use, distribution, and reproduction in any medium, provided the original work is properly cited. doi:10.1017/S1755691021000335 


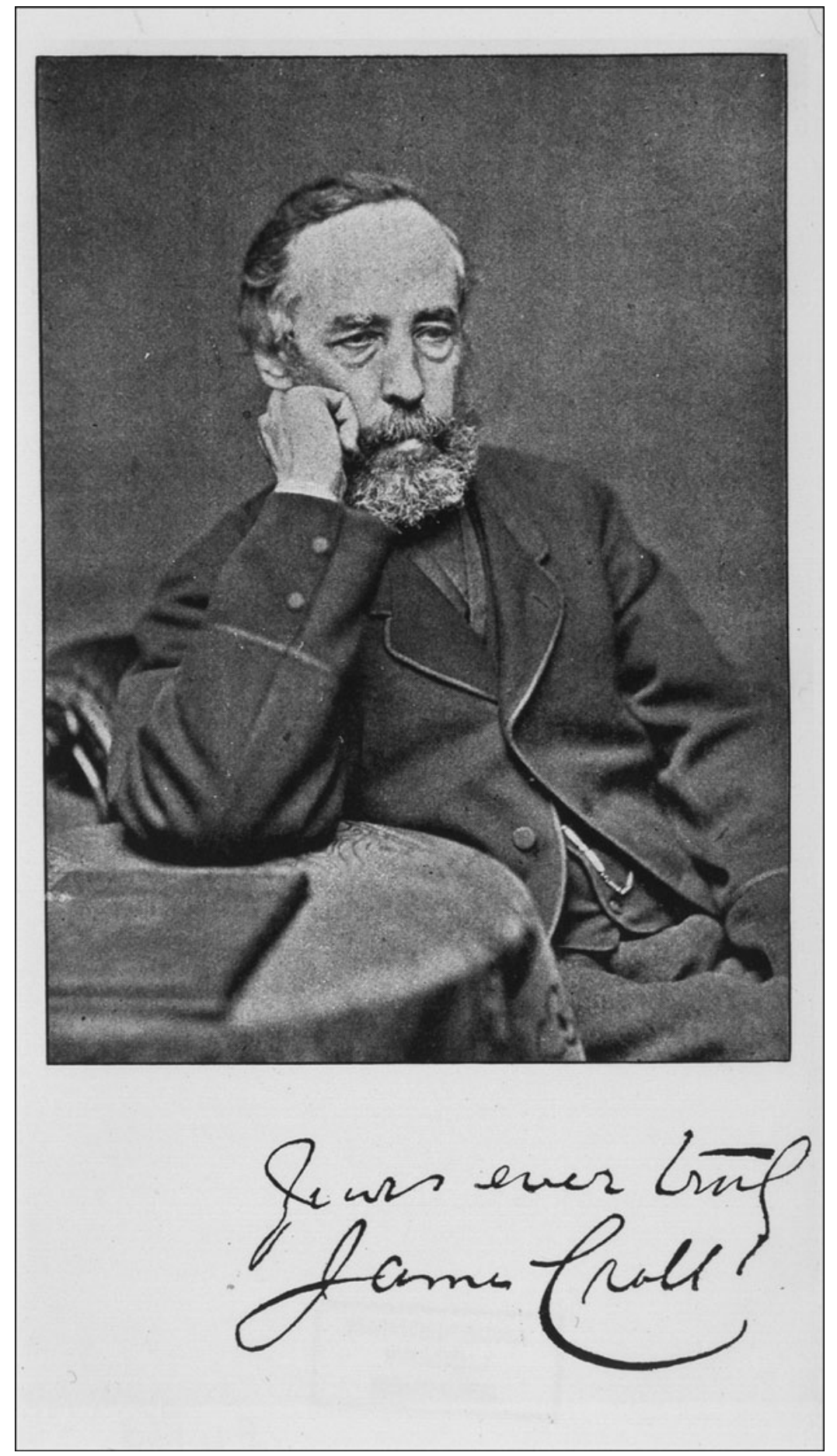

Figure 1 Portrait and signed inscription of James Croll from the frontispiece of Irons (1896).

the Commonwealth socio-political reform newspaper, and having produced his Philosophy of theism, Croll spent almost eight years (1860-1867) as a janitor at Anderson's College and Museum in Glasgow. There he found the time and resources to develop and record the insights which were to propel him into the scientific mainstream. Of Anderson's (also known as the Andersonian Institution and Anderson's University [Edwards 2021a]), a predecessor institution to Strathclyde University, Croll (1887, p. 30) was to say 'I have never been in any place so congenial to me as that institution proved'.

His tasks at Anderson's College were largely performed by his younger, physically challenged brother David, who lived on the premises with James and his wife Isabella. Croll had 'a good deal of spare time....[and] generally a few hours a day of a quiet time for reading and study' (ibid., p. 31). The institution provided Croll with a magnificent scientific library and a paper on electromagnetism (Croll 1861) represented his first foray into conventional science, soon followed by contributions on such topics as chemistry, heat, tidal waves, the Earth's rotation and lunar motion, climate change and glaciology. More than twenty items were to flow from his pen before Archibald Geikie ('the most distinguished and influential geologist of the period' [Tanner et al. 2019, p. 1]) lured Croll to work as secretary in the new Geological Survey office in Edinburgh. Health issues while working in Edinburgh led him to 'feel a sort of half regret that I had ever left my former situation' (Croll 1887, p. 36). Faced with ill health, Croll had felt impelled to tender his resignation from the Geological Survey and the rest of his life was adversely affected by his fight to obtain the pension to which he felt entitled, and one which would enable him and his wife to live without struggle (Edwards \& Robinson 2021). 


\section{Genius}

'Genius' may be an over-used term, and James Croll was always a genius in the sense of his ability to transform himself through self-education to become a scientist of world renown. He may have been of humble origins, but it should be noted that his path from millwright to sage was studded with not a little recognition. He was elected as a deacon of his church in Paisley; his biographer's father saw enough in him to set him up as a tea merchant in Elgin; his janitorial post at Anderson's College was gained in competition with 'upwards of 200' others; a year after his climate change paper in the Philosophical Magazine, Andrew Crombie Ramsay, President of the Geological Society of London, wrote to Principal James David Forbes of the University of St Andrews saying (of Croll) - 'I have a very high opinion of him, he is a singularly modest man, and I suspect is almost quite self-educated'. The events of 1876 were outlined above (cf. Edwards 2021a) and the first name on his nomination certificate for Fellowship of the Royal Society of London was that of Charles Darwin. Other supporters were also illustrious, including John Tyndall, Andrew Ramsay, Archibald Geikie and William Thomson (Lord Kelvin). Furthermore, he could number these individuals along with the likes of Charles Lyell, Joseph Dalton Hooker and Alfred Russell Wallace amongst his correspondents. Although not a Fellow of the Geological Society of London, that institution bestowed three of its awards upon him (Brassington 2021; Edwards \& Robinson 2021). In his history of the Geological Survey of Great Britain, Edward Bailey (1952, p. 77) wrote:

'James Croll...though appointed in 1867 , it was not as a field geologist, nor yet as one of the scientists of the Headquarter staff. Nevertheless, it is impossible to pass over his advent in silence, since he was the most remarkable man ever enrolled in the Geological Survey, in fact a prodigy.'

Croll's achievements may have occurred at a time when ideas and discoveries were proliferating at an astonishing rate, and not simply generated by those of privileged backgrounds (Porter 1978; Secord 2000; Desmond 2001; Barton 2003; Rudwick 2014), yet it would seem unreasonable, if not preposterous, to regard Croll's accomplishments as anything other than astounding.

\section{This volume}

For those who read the Special Issue from cover to cover, it will be apparent that there is some overlap in material. This is inevitable where authors are sometimes accessing the same information - but usually from different perspectives - and where efforts are made to render papers readable as stand-alone contributions.

The paper by Mike Robinson (2021) is an intentionally popular consideration of the environmental, social and economic influences upon the young James Croll and their relevance to his career choices and beyond. His friends, religious and otherwise, along with health and financial struggles are seen as germane to his independent, intellectual development. Even the formalisation of his change of surname, from Croil or Croyl to Croll, may reflect an effort to counteract vernacular derogatory connotations of the name Croil. The question of his surname change is examined in more detail in the first of three successive contributions leaning heavily upon new archival information. Kevin Edwards \& Mike Robinson (2021) emphasize some of the less studied or recognised features of Croll's biography in order to provide a personal context for Croll the man and the scholar of sciences and religion. These include his family history, his many homes, his health, participation in learned societies and attitudes to collegiality, financial problems (especially the failed efforts to secure a larger pension), and friendship. It would appear that Croll felt most comfortable with his family, religious friends and work colleagues. He obviously found learned societies and opponents of his scientific ideas sometimes unpalatable; scientifically, he was not a clubbable individual.

The years 1864 and 1875 bracket the period when Croll's initial ground-breaking theoretical and empirical contributions on astronomically-related climate change appeared. These gained the attention of people of the eminence of Charles Lyell, John Tyndall, William Thomson, Charles Darwin and Alfred Russell Wallace. Kevin Edwards (2021a) argues, however, that it was the year 1876, when many academic honours were bestowed on Croll, including Fellowship of the Royal Society of London and an honorary LL.D. from the University of St Andrews, that represented the summit of his scientific life. The background to the award of these accolades is explored, along with discussion as to why he never became a Fellow of his national academy, the Royal Society of Edinburgh (RSE). In a related paper, Laura Brassington (2021) also considers Croll's non-membership of the RSE when viewed as part of a strategic, scientific engagement set apart from learned society affiliation - indeed, Croll had an aversion to the 'cold materialistic atmosphere around scientific men'. She highlights his pursuit of an education for theistic ends and a preference for the meritocratic structures of the Geological Survey and the Philosophical Magazine.

Diarmid Finnegan (2021) examines the interplay of science, metaphysics and Calvinism as drivers for Croll's faith. For Croll, science had to be conducted on metaphysical principles and the cosmos was fully determined by a perfect intellect. This conviction was central to Croll's scientific theories and shaped his own self-understanding. He spent much of his life looking for an opportunity to return to his metaphysical inquiries and never lost the belief that 'religion, philosophy, and science will go hand in hand' (Irons 1896, p. 312).

The celestial mechanical, mathematical and astronomical background to Croll's research from classical times onwards is charted by Malcolm Longair (2021). He shows how Croll's development and augmentation of the astronomical background to climate change was adopted by Milutin Milankovitch in the 1920s-1930s. Although Croll's contributions became diminished for several generations, it is stressed that his novel insights have been demonstrated to have been basically correct and he was not alone for having insights far ahead of his time.

In a paper which bridges humanistic and scientific dimensions, James Fleming (2021) examines Croll's astronomical theory of ice ages and suggests that he was involved in a personal quest for a general theory of the unity of nature, linking religion, philosophy and science. Croll's insight that orbital elements triggered feedbacks leading to complex changes in climate, seasonality, ocean currents, ice sheets, radiative forcing, plant and animal life, placed his theory of the Glacial Epoch at the nexus of astronomy, terrestrial physics, and geology. In effect, Croll was an early proponent of Earth-system science. He maintains that what Darwin did for life forms, Croll accomplished for climate change.

Alastair Dawson (2021) analyses the oceanographic contributions, demonstrating that Croll had calculated from first principles the quantities of heat delivered by ocean currents to high latitude areas, and he understood how this heat supply may have altered drastically during ice ages. He shows how the use of data from the expedition of HMS Challenger enabled Croll to test his theories of ocean circulation using real data. This led him into a bruising academic conflict with the establishment scientist William Carpenter. Dawson reprises the notion that Croll's insights were far ahead of his time, as does David Sugden, acting as James Croll's alter ego. In Croll \& Sugden (2021), it is submitted that the pioneer's modelled estimates of the Antarctic ice 
sheet and its dimensions (Croll 1879) were not improved upon until John Glen (1955) developed a realistic flow law for ice some three quarters of a century later. Furthermore, Croll is to be admired for his use of a systems approach in the search for scientific understanding.

James Rose (2021) considers the differing perspectives of Charles Lyell, the Geikie brothers (Archibald and James) and Croll, regarding terrestrial glacial sediments and landforms. $\mathrm{He}$ argues persuasively that Croll may have been a reluctant geologist, but that he was a very good one. Indeed, he was influenced by a relatively unacknowledged 'Glasgow School' of glacial geologists, while also sharing in the development of land-ice glacial theories as exemplified particularly by James Geikie.

Polychronis Tzedakis \& Eric Wolff (2021) discuss Croll's orbital theories and his proposal that astronomical forcing is only able to produce glaciation by means of climate feedbacks that amplify the small effects of varying seasonal irradiation. $\mathrm{He}$ also understood the significance of interglacial deposits in furnishing evidence for multiple glaciations. The marine sedimentary record was able to deliver a test of astronomical theories as outlined by both Croll and later by Milankovitch, a century after the publication of Croll's monumental 1875 book Climate and time in their geological relations. While hindsight allows us to be critical of early theories, it is of value to explore how aspects of Croll's concepts fit within the context of the modern theory of ice ages.

Feedback mechanisms in the Earth system were also a focus for Roy Thompson (2021), who explains how Croll's fundamental recognition of this notion foreshadowed global warming. This, however, was one of a series of legacy issues embraced by Croll and covering an astonishing range of topics relevant to climate and wider environmental science including the melting of icecaps and sea-level rise, orbital changes, and the temperature of space and its bearing on terrestrial physics.

Jo Woolf (2021) explored ways to popularise Croll involving a broad spectrum of actual and potential approaches such as talks and lectures, exhibitions, theatrical events, print and online articles and educational tourist trails. It was an opportunity for expression and creativity in a manner which reminds us that Croll, was once a young lad, 'full of fun and frolic', undeterred by impediments of health, early education and social mores and someone who might be opened up to interpretation by people of different ages and backgrounds.

A final contribution by Kevin Edwards (2021b) examines and collates source materials for investigating the life of James Croll. The paper is organized around the topics of the Autobiographical Sketch and the Memoir of his life and work contained within the volume produced by James Campbell Irons (1896), publications by Croll, aspects of his genealogy, manuscript sources in publicly accessible archives and in private ownership, and other published outputs. It is shown that a wealth of resources with which to inform his biography is available.

\section{Acknowledgements}

My greatest appreciation is tendered to those who have contributed the thought and energy to producing papers timeously in honour of an under-appreciated man, and to the referees who have lent their constructive expertise. It is a pleasure to acknowledge the support of Mike Robinson, Chief Executive of the Royal Scottish Geographical Society, and the RSGS itself, for backing this venture. Mike has acted as a champion for James Croll, both within Perthshire and beyond, including the establishment of the Croll Garden within Lord John Murray House, headquarters of the RSGS. Thanks are also extended to the Quaternary Research Association whose co-sponsorship of the online meeting on James Croll, held on 16 April 2021, represented continued faith in the undertaking after the coronavirus pandemic prevented the intended lecture- and field-based gathering in Perth. Gratitude is owed to the Editorial Board of Earth and Environmental Science Transactions of the Royal Society of Edinburgh for their endorsement and encouragement of this publication. Susie Cox and her colleagues at Cambridge University Press are thanked for their advice and professionalism.

\section{References}

Alexander, J. 1900. Stories of self-help. Recent and living examples of men risen from the ranks. London: S.W. Partridge \& Co.

Anon. [= Croll, J.]. 1857. The Philosophy of theism: an inquiry into the dependence of theism on metaphysics and the only possible way of arriving at a proof of the existence of God. London: Ward \& Co.

Bailey, E. 1952. Geological Survey of Great Britain. London: Thomas Murby \& Co.

Barton, R. 2003. 'Men of science': Language, identity and professionalization in the mid-Victorian scientific community. History of science 41, 73-119.

Bol'shakov, V. A., Kapitsa, A. P. \& Rees, W. G. 2012. James Croll: a scientist ahead of his time. Polar Record 48, 201-205.

Brassington, L. 2021. The 'janitor-geologist' and the 'cold materialistic scientific men': James Croll's navigation of scientific societies. Earth and Environmental Science Transactions of the Royal Society of Edinburgh. doi:10.1017/S1755691021000141

Croll, J. 1861. XXXVIII. Remarks on Ampère's experiment on the repulsion of a rectilinear electrical current on itself. The London, Edinburgh, and Dublin Philosophical Magazine and Journal of Science 21, 247-250.

Croll, J. 1864. XIII. On the physical cause of the change of climate during geological epochs. The London, Edinburgh, and Dublin Philosophical Magazine and Journal of Science 28, 121-137.

Croll, J. 1875. Climate and time in their geological relations: a theory of secular changes of the Earth's climate. London: Daldy, Isbister \& Co.

Croll, J. 1879. On the thickness of the Antarctic ice, and its relations to that of the glacial epoch. Quarterly Journal of Science 9, 1-34.

Croll, James, 1887 (published 1896). Autobiographical sketch of James Croll. In J. C. Irons Autobiographical sketch of James Croll LL.D., F.R.S., etc. with memoir of his life and work, 9-41, Prefatory note, 5. London: Edward Stanford.

Croll, J. 1890. The philosophical basis of evolution. London: Edward Stanford.

Croll, J. \& Sugden, D., 2021. On the thickness of the Antarctic ice, and its relations to that of the glacial epoch. Earth and Environmental Science Transactions of the Royal Society of Edinburgh. doi.org/10. 1017/S1755691021000050

Cvijanovic, I., Lukovic, J. \& Begg, J. D., 2020. One hundred years of Milanković cycles. Nature Geoscience 13, 524-525.

Dawson, A. 2021. The oceanographic contribution of James Croll. Earth and Environmental Transactions of the Royal Society of Edinburgh. doi.org/10.1017/S1755691021000086

Desmond, A., 2001. Redefining the X axis: "Professionals," Amateurs" and the making of mid-Victorian biology - a progress report. Journal of the History of Biology, 34(1), pp.3-50.

Edwards, K. J. 2021a. James Croll and 1876 - an exceptional year for a 'singularly modest man'. Earth and Environmental Science Transactions of the Royal Society of Edinburgh. doi.org/10.1017/ S1755691021000074

Edwards, K. J. 2021b. In search of James Croll: archives, genealogy, publications and other resources. Earth and Environmental Transactions of the Royal Society of Edinburgh. doi:10.1017/S1755691021000323.

Edwards, K. J. \& Robinson, M. 2021. James Croll - a man 'greater far than his work'. Earth and Environmental Science Transactions of the Royal Society of Edinburgh. doi.org/10.1017/S1755691021000232.

Fairbridge, R.W., 1961. Convergence of evidence on climatic change and ice ages. Annals of the New York Academy of Sciences, 95(1), pp.542-579.

Finnegan, D.A., 2021. Science, metaphysics and Calvinism: the God of James Croll. Earth and Environmental Science Transactions of the Royal Society of Edinburgh. doi.org/10.1017/S1755691021000190

Fleming, J. R. 2006. James Croll in context: the encounter between climate dynamics and geology in the second half of the nineteenth century. History of Meteorology 3, 43-53.

Fleming, J. R., 2021. Cosmic connections: James Croll's influence on his contemporaries and his successors. Earth and Environmental Science Transactions of the Royal Society of Edinburgh. doi.org/10.1017/ S1755691021000098

Goudie, A. 1983. Environmental change. $2^{\text {nd }}$ edn. Oxford: Clarendon Press.

Glen, J. W. 1955. The creep of polycrystalline ice. Proceedings of the Royal Society, A 228, 519-38. 
Hamlin, C. 1982. James Geikie, James Croll, and the eventful ice age. Annals of Science 39, 565-583.

Hilgen, F. J. 2010. Astronomical dating in the 19th century. Earth-Science Reviews 98, 65-80.

Hays, J. D., Imbrie, J. \& Shackleton, N. J. 1976. Variations in the Earth's orbit: pacemaker of the ice ages. Science 194, 1121-1131.

Imbrie, J. \& Imbrie, K. P. 1979. Ice ages: solving the mystery. London: Macmillan.

Irons, J. C. 1896. Autobiographical sketch of James Croll LL.D., F.R.S. etc. with memoir of his life and work. London: Edward Stanford.

Longair, M., 2021. James Croll, celestial mechanics and climate change. Earth and Environmental Science Transactions of the Royal Society of Edinburgh. doi.org/10.1017/S1755691021000165

Milankovitch, M. 1930. Mathematische Klimalehre und Astronomische Theorie der Klimaschwankungen. Handbuch der Klimatologie. In: Köppen W, Geiger R (eds). Vol. 1. Berlin: Borntraeger. Pp. 1-176.

Milankovitch, M. 1941. Kanon der Erdbastrahlung und seine Anwendung auf des Eiszeitenproblem. Königlich Serbische Akademie Special Publication, 133, pp.1-633.

Muller, R.A. and MacDonald, G.J., 1997. Glacial cycles and astronomical forcing. Science, 277(5323), pp.215-218.

Pearce, F. 2018. Caretaker who solved the ice age mystery. New Scientist 239, 34-35.

Porter, R. 1978. Gentlemen and geology: the emergence of a scientific career, 1660-1920. The Historical Journal 21, 809-836.

Robinson, M. 2021. Dr James Croll: A product of his environment? An exploration of the natural, social, personal and economic factors that influenced his extraordinary life. Earth and Environmental Transactions of the Royal Society of Edinburgh. doi.org/10.1017/ S1755691021000104
Rogers, J. J. W. 1993. A history of the Earth. Cambridge: Cambridge University Press.

Rose, J. 2021. Lyell, the Geikies and Croll's observations on terrestrial glacial sediments and landforms. Earth and Environmental Science Transactions of the Royal Society of Edinburgh. doi.org/10.1017/ S1755691021000116

Rudwick, M.J., 2021. Earth's deep history. University of Chicago Press.

Secord, J. A. 2000. Victorian sensation: the extraordinary publication reception, and secret authorship of Vestiges of the Natural History of Creation. Chicago: University of Chicago Press.

Sugden, D. E. 2014. James Croll (1821-1890): ice, ice ages and the Antarctic connection. Antarctic Science 26, 604-613.

Tasch, P. 1986. James Croll and Charles Lyell as glacial epoch theorists Earth Sciences History 5, 131-133.

Tanner, J., Betterton, J. Neller, R. \& Craig, J. 2019. Introduction: aspects of the life and works of Sir Archibald Geikie. In Betterton, J., Craig, J., Mendum, J. R., Neller, R. \& Tanner, J. (eds) Aspects of the life and works of Archibald Geikie, 1-5. London: Geological Society of London, Special Publication 480.

Thompson, R., 2021. Croll, feedback mechanisms, climate change and the future. Earth and Environmental Science Transaction of the Royal Society of Edinburgh. doi.org/10.1017/ S1755691021000153

Tzedakis, P. C. and Wolff, E. W., 2021. James Croll and geological archives: testing astronomical theories of ice ages. Earth and Environmental Science Transactions of the Royal Society of Edinburgh. doi.org/10.1017/S1755691021000177

Woolf, J. 2021. Popularising Croll: an opportunity for expression and creativity. Earth and Environmental Science Transactions of the Royal Society of Edinburgh. doi.org/10.1017/S1755691021000062 